\title{
A NOTE ON THE DETERMINATION OF $\beta$-GLUCURONIDASE ACTIVITY IN URINE
}

\author{
BY
}

\author{
M. A. M. ABUL-FADL \\ From the Chester Beatty Research Institute, Institute of Cancer Research, Royal Cancer Hospital, London
}

(RECEIVED FOR PUBLICATION DECEMBER 22, 1956)

Interest in urinary $\beta$-glucuronidase has recently developed from the work of Boyland, Wallace, and Williams (1955), who found high levels of this enzyme in the urine of patients with carcinoma of the bladder. The method used by these authors was modified from that of Talalay, Fishman, and Huggins (1946). After a careful study of the following points, however, it was found necessary to reinvestigate and modify this method.

\section{Adjustment of the pH Value}

Adjustment of the $p \mathrm{H}$ value is important for two reasons.

(1) Before incubating the urine with the acetate buffer-substrate mixture, it must be adjusted to the correct $p \mathrm{H}$, since its buffering capacity may exceed that of the acetate buffer, and hence the final $p \mathrm{H}$ of the mixture will be closer to that of the original urine. The acetate buffer itself must not be less than $0.1 \mathrm{M}$ to be of an effective concentration in undiluted urine. After accurate adjustment using a $p \mathrm{H}$ meter, $\beta$-glucuronidase activity was determined at $p \mathrm{H} 4.5$ and at $p \mathrm{H} 5.2$ in over 250 24-hour collections of normal and pathological urines. Also the enzyme activity was investigated over the complete $p \mathrm{H}$ range of 3.6 to 5.6 , using acetate buffer in a number of normal and pathological urines, with and without dilution of urine. In the majority of these cases the enzyme activity at $p \mathrm{H}$ 5.2 in undiluted urine was higher than that at $p \mathrm{H}$ 4.5. The difference in activity at the two $p \mathrm{H}$ values in some pathological cases was considerable. On diluting the urine, and especially in the presence of added protamine, the activity in normal urine was optimal at $p \mathrm{H} 4.5$.

(2) At the end of the incubation period, when alkaline buffer solution was added to develop the phenolphthalein colour, the adjustment of $p \mathrm{H}$ is again critical. The colour production is maximum between $p H 10.4$ and 11.2 , but is very unstable in solutions which are more alkaline than $p \mathrm{H}$ 10.6. Hence the importance of an efficient buffer solution, the addition of which to the mixture will always produce a final $p \mathrm{H}$ within the range 10.4 to 10.5 where the maximum colour is combined with stability. Glycine buffer used by previous workers was found unsatisfactory for this purpose, while the sodium carbonate solution described below proved to be much more efficient.

\section{The Substrate Concentration}

The $\mathrm{Km}$ for urinary $\beta$-glucuronidase with phenolphthalein glucuronide substrate was found to be 0.00108 , thus the optimum substrate concentration is slightly over $2 \mathrm{mM}$. Hence the considerable variation in enzyme activity at different substrate concentrations. In the Fishman unit, which has been commonly used for expressing this enzyme activity in blood plasma and certain other body fluids, $1 \mathrm{mM}$ substrate concentration was used. It was thought advisable, for the sake of comparison, to use the same substrate concentration $(\mathrm{mM})$.

\section{Enzyme Activity in Undiluted and Diluted Urine}

The presence of certain $\beta$-glucuronidase inhibitors in urine has already been shown (Abul-Fadl, 1957). The activation of the urinary enzyme by protamine after removing the inhibitory effect by dilution or dialysis was also described. Thus, in order to determine the total amount of enzyme excreted, it would be necessary to test the activity in diluted urine at $p \mathrm{H} 4.5$ and in the presence of protamine. A dilution of 10 was found to be adequate in most cases to overcome the inhibitory effect. In order to determine the enzyme activity which is effective in the bladder, the undiluted urine adjusted to the correct $p \mathrm{H}$ should be used with the minimum possible volume of concentrated buffered substrate. 


\section{Contaminants in Urine}

Infection.-Specimens of sterile normal urine were inoculated with Escherichia coli, diphtheroids, B. proteus, Staphylococcus pyogenes, streptococci, and Streptococcus faecalis.

The glucuronidase activity was determined at pH 4.5 and 5.2 in dilute and undiluted, infected and sterile control urines, which had been incubated at $37^{\circ} \mathrm{C}$. for 24 hours, then filtered clear and adjusted to the correct $p \mathbf{H}$.

Diphtheroids did not seem to produce any change on the urinary $\beta$-glucuronidase activity, while staphylococcus and streptococcus infections caused an apparent increase (15-20\%) in the enzyme activity of undiluted urine measured at both $p \mathrm{H} 4.5$ and at 5.2. No significant change, however, could be detected when the enzyme activity was measured in diluted urine. E. coli, on the other hand, produced an apparent decrease (about 15\%) in enzyme activity at $p \mathrm{H} 4.5$ in undiluted urine, but produced an increase (about $50 \%)$ in the $\beta$-glucuronidase activity at $p \mathrm{H} 5.2$. With $B$. proteus infection, however, the enzyme activity at $p \mathrm{H} 4.5$ was markedly decreased (30$50 \%)$; while that at $p \mathrm{H} 5.2$ was less affected (10-20\% decrease). This enzyme destruction by $B$. proteus might be attributed to the high alkalinity produced by this organism $(p \mathrm{H} \mathrm{9.3).} \mathrm{Strepto-}$ coccus faecalis seemed also to cause some decrease (about $10 \%$ ) of the urinary $\beta$-glucuronidase activity at $p \mathrm{H} 4.5$ and 5.2.

Cellular Matter.-Pus cells did not seem to affect the $\beta$-glucuronidase activity of filtered urine. Fishman, Springer, and Brunetti (1948) found that human erythrocytes contained little or no $\beta$-glucuronidase activity. Other cellular matter, such as epithelial cells, in urine was found to contain variable levels of $\beta$-glucuronidase activity which, sometimes, were extremely high.

Non-cellular Contaminants.-Diluted blood plasma was found to contain at least five times as much $\beta$-glucuronidase activity as undiluted urine. Serous exudates from inflamed areas were found to be very high in $\beta$-glucuronidase activity, and, as contaminants in urine, would contribute to elevated enzyme levels. Post-operative specimens of urine showed, in most cases, very high $\beta$-glucuronidase activity. Bile, ammonium salts, etc. (Abul-Fadl, 1957), were found to inhibit the enzyme activity in undiluted urine, but their effect was overcome by dilution. Antibiotics did not seem to have a direct inhibitory effect on the urinary enzyme in vitro, but their administration (especially the terramycin group) caused a considerable diminution in $\beta$-glucuronidase excretion in urine.

\section{Method}

Acetate Buffer Solutions.-The following were used: $2 M$ Buffer $p H$ 5.2.-Crystalline sodium acetate A.R. $\left(\mathrm{C}_{2} \mathrm{H}_{3} \mathrm{O}_{2} \mathrm{Na} .3 \mathrm{H}_{2} \mathrm{O}\right), 43.5 \mathrm{~g}$., and $4.6 \mathrm{ml}$. glacial acetic acid A.R. are dissolved in $100 \mathrm{ml}$. distilled water.

$2 M$ Buffer $p H 4$ 4.5.-Crystalline sodium acetate, $26.1 \mathrm{~g}$., and $12 \mathrm{ml}$. glacial acetic acid are dissolved in $100 \mathrm{ml}$. distilled water.

$0.05 M$ Buffer pH 4.5 Containing $0.05 \%$ Protamine Sulphate.-Protamine sulphate, $50 \mathrm{mg}$., is dissolved in $20 \mathrm{ml}$. distilled water, $2.5 \mathrm{ml}$. of the above $2 \mathrm{M}$ acetate buffer solution, $p \mathrm{H} 4.5$, is added and the volume made up to $100 \mathrm{ml}$. with distilled water.

In each case the $p \mathrm{H}$ should be checked with a $p \mathrm{H}$ meter and solutions kept in the cold, preserved with chloroform.

$\mathbf{M} / \mathbf{5 0}$ Substrate Solutions.-Crystalline phenolphthalein glucuronide (Sigma), $50 \mathrm{mg}$., is dissolved in $5 \mathrm{ml}$. distilled water and kept in the refrigerator. This solution was kept for over three months without deterioration.

Concentrated Sodium Carbonate Solution pH 10.5. One. hundred and fifty millilitres of $20 \%$ sodiun hydroxide solution are added to $11.8 \%$ sodium bicat bonate solution and the $p \mathrm{H}$ adjusted to 10.5 using a $p$ meter.

Standard Phenolphthalein Solution.-Phenolphthalein, $18 \mu \mathrm{g}$. $/ \mathrm{ml}$. (1 ml. = 1 unit), is dissolved in $100 \mathrm{ml}$. ethanol, $\triangle$ then diluted to 1 litre with distilled water. A calibration curve (0.5-2 units) should be prepared with each new batch of the above sodium carbonate solution.

The complete 24-hour urine collection, preserved with benzene-thymol and kept in the cold, is subjected to a preliminary analysis of volume, specific gravity, $p \mathrm{H}$, and tested for albumin and any other expected abnormality. The $p \mathrm{H}$ in a clear filtered specimen is adjusted to 5.2 using 3 . a $p \mathrm{H}$ meter if possible. Another specimen is adjusted to $p \mathrm{H}$ 4.5. All estimations are made in duplicate.

Enzyme Activity in Undiluted Lrine.-A carefully 0 measured quantity, $0.05 \mathrm{ml}$., of $\mathrm{M} / 50$ substrate solution and $0.05 \mathrm{ml}$. of $2 \mathrm{M}$ acetate buffer of the appropriate $p \mathrm{H} \frac{\mathrm{D}}{\mathrm{O}}$ are introduced into a clean stoppered tube and $1 \mathrm{ml}$. of urine adjusted to the correct $p \mathrm{H}$ is added. Two blank $N$ tubes are used, one containing no urine but $0.1 \mathrm{ml}$. of buffered substrate and $1 \mathrm{ml}$. distilled water, the other $\mathcal{N}$ containing $1 \mathrm{ml}$. of urine alone. After incubation for 18 hours in a water-bath at $37^{\circ} \mathrm{C}$., the contents of the $O$ two blank tubes are mixed together and $2 \mathrm{ml}$. sodium carbonate solution $p \mathrm{H} 10.5$ is added to each of the test $\stackrel{\circ}{=}$ and blank tubes. The volume in each tube of the test $\Phi$ is then made up to $4 \mathrm{ml}$. with distilled water, mixed, and centrifuged if necessary to remove any precipitate or turbidity. The test is read against the blank on a spectrophotometer at $550 \mu \mathrm{m}$. The activity is expressed 
in units, 1 unit liberating $1 \mu \mathrm{g}$. phenolphthalein from $1 \mathrm{mM}$ substrate per hour at $37^{\circ} \mathrm{C}$.

Enzyme Activity in Diluted Urine.- $\mathrm{M} / 50$ substrate, $0.05 \mathrm{ml}$., is introduced into a stoppered tube and $1 \mathrm{ml}$. urine, adjusted to $p \mathrm{H} 4.5$ and diluted 10 times with $0.05 \mathrm{M}$ acetate buffer containing protamine, is added. After incubation for 18 hours at $37^{\circ} \mathrm{C}$., $1 \mathrm{ml}$. carbonate solution is added and the procedure is completed as above.

Normal Valuzs.-Analysis conducted on 25 healthy individuals of both sexes ranging from 5 to 47 years of age gave the following values.

\begin{tabular}{|c|c|c|c|}
\hline & \multicolumn{3}{|c|}{ Units $/ m l$. Urine } \\
\hline & Undilute & Urine & Diluted Urine \\
\hline $\begin{array}{l}\text { Range . . } \\
\text { Average }\end{array}$ & $\begin{array}{c}p \mathrm{H} 4.5 \\
0.52-2.36 \\
1.65\end{array}$ & $\begin{array}{l}p \text { H } 5 \text { 2 } \\
0.45-3.2 \\
1.73\end{array}$ & $\underset{3 \cdot 5}{1 \cdot 1-7 \cdot 5}$ \\
\hline
\end{tabular}

\section{REFERENCES}

Abul-Fadl, M. A. M. (1957). Biochem. J., 65, 16P.

Boyland, E., Wallace, D. M., and Williams, D. C. (1955). Brit. J. Cancer, $9,62$.

Fishman, W. H., Springer, B., and Brunetti, R. (1948). J. biol. Chem., 173, 449.

Talalay, P., Fishman, W. H., and Huggins, C. (1946). Ibid., 166, 757. 